modern audiences, again making it a bit more digestible at the level of undergraduates and general interest readers, although more seasoned Harvey scholars might also appreciate the added clarity, or where there is confusion, he has left the original Latin. For example, making reference to the 1928 translation by Chauncey Leake, Carty identifies confusion over the vena arteriosa and arteriae venosae for which Leake criticised Willis, and so Carty diplomatically leaves the original Latin in the text as a point for Harvey scholars to consider.

As Harvey himself was in some places a bit lax in providing notes, Carty has also filled in some of these gaps by providing added analysis and context in footnotes which would be helpful for readers who might not yet have had exposure to secondary analysis of Harvey's work. For example, Harvey's reference to 'the learned Hofmann' is brief in the original translation, and Carty provides further information on who Caspar Hofmann was, and how he and Harvey's correspondence further refined Harvey's theory on the movement of the the blood through the heart. Moreover, throughout the notes, there is consistent emphasis on and explanations of Harvey's philosophical leanings, which keep the reader firmly grounded in the broader landscape of scientific thought at the time. For example, when Harvey mentions 'superior bodies', Carty reminds readers how this alludes to Aristotelian cosmic physics; or, when Harvey is discussing decayed material, the notes expand on how Harvey subscribed to some notion of spontaneous generation and provide helpful detail on this theory and its origin, which the general reader or new student in the history of science may not have yet encountered. As a teaching resource, these notes add great value to the primary text. These features all show the sign of a careful and thorough consideration of Harvey's writing and Willis's translation, as well as consultation of appropriate secondary literature on the life and work of William Harvey; this new edition of De Motu Cordis will be of benefit for both instructors and students.

Brigit Ramsingh

University of Central Lancashire, UK

doi:10.1017/mdh.2017.15

Shelley Z. Reuter, Testing Fate: Tay-Sachs Disease and the Right to be Responsible (Minneapolis, MN: University of Minnesota Press, 2016), pp. 264, \$27,00, paperback, ISBN: 978-0-8166-9996-4.

What is the political and epistemological significance of racialisation in medicine? What are the social processes by which racialisation occurs? Shelley Z. Reuter's thoughtprovoking Testing Fate makes a much-needed contribution to the scholarly literature on the interconnections between racialisation, disease construction, knowledge production and political economy. While much has been written about race and sickle cell disease, there has been remarkably little critical scholarship probing the history of Tay-Sachs and its racialisation. Building on Michael Omi and Howard Winant's concept of racial formation, Reuter argues that making Tay-Sachs an exclusively Jewish disease can best be understood as a 'racial project'. This engaging book thus fills an important lacuna in the literature on racial formation in medicine.

First known as amaurotic familial idiocy in Jewish immigrants by physicians in both the UK and US in the late 1800s, Tay-Sachs is a rare and devastating neurological disease with no treatment. In 1970, there were only about 50-60 cases per year in the US and Canada, 40-45 of which occurred in people of Ashkenazi Jewish descent. Most 
accounts of this autosomal recessive disease have ignored non-Jewish Tay-Sachs. Since mass screening for Tay-Sachs began in the 1970s, the disease has been largely eliminated in Jews. Consequently, most cases now occur in non-Jewish groups. Yet, despite evidence to the contrary, Tay-Sachs disease, together with sickle cell disease, remain prototypical race-specific diseases in the scientific and popular imagination.

Testing Fate is a nuanced transnational analysis of the historical processes by which TaySachs Disease became a marker of racial difference in Jews. Reuter organises the book into three parts - 'Pathologizing the Other'; 'Imag(in)ing Difference'; and 'Paradoxical Citizenship'. In the first two chapters of this theoretically rich and deeply researched book, she draws on sociological theories of disease construction in Michel Foucault and Nicholas Rose, critical race studies and close readings of scientific texts to demonstrate the almost immediate attachment of Tay-Sachs disease to Jewish bodies in the late 1800s. Although there was large-scale immigration of eastern Europeans, many of them Jewish, to both the UK and the US in the late nineteenth century, Reuter provides fascinating evidence that the processes of racialisation, while intersecting and cross-fertilising at certain historical moments, differed in the United Kingdom (UK) and the United States (US) - and had different outcomes. In the US, the identification of Tay-Sachs in eastern European Jews drew on and contributed to cultural anxieties about disease race and degeneration in a period of rising nativism and unemployment. Stereotyping descriptions of Tay-Sachs were part of scientifically informed policies that materialised in angry immigration debates and ultimately the Immigration Act of 1924 that severely restricted immigration from certain regions of the world. In the UK, on the other hand, Jewish immigration mobilised concerns about integration, rather than exclusion, with established Jewish organisations, such as the Jewish Board of Guardians actively intervening to assimilate the eastern European other. Interestingly, it is in these discourses of assimilation in the UK that Reuter locates the origins of 'the right to be responsible' (p. 19) or medical 'responsibilisation', as represented in twentieth-century genetic counselling and screening programs embraced by Ashkenazi Jews in the US. For a variety of reasons, mass screening never took off in the UK.

In the second section of her book, Reuter examines the rhetorical power of visual imagery in scientific descriptions and online portrayals, such as YouTube videos, of Tay-Sachs patients. Reductive scientific imagery deployed by Jewish and non-Jewish scientists was intertwined with and central to anti-immigrant discourses. With privileged access to the 'truth', scientific visual imagery of cells, tissues, disabled children and the signature cherry-red spot in the macula of affected babies contributed to the construction of categories of Jews as fixed types. In 'making a spectacle of these children' (p. 124), online portrayals of Tay-Sachs served multiple functions, including education, cultivation of a sense of belonging and construction of categories of personhood, as well as a 'morbid voyeurism'. Both types of visual representations shaped and were shaped by racialised narratives.

In the last section of the book, Reuter situates responsibilisation in the political and cultural context of neo-liberalism. Linking historical scientific discourses to contemporary practices of biocitizenship, Testing Fate raises important questions of 'constrained agency' in the context of the complex and changing relationships of Jewish communities to racialisation. With the identification of Hexoaminadase A deficiency in Tay-Sachs patients in 1969, mass screening for enzyme activity became a possibility, a 'right', and a societal imperative. Because there was no treatment for Tay-Sachs, containing the disease turned on prevention, either management of marriage between carriers or 
more commonly prenatal screening followed by abortion. Racialisation of Tay-Sachs thus served exclusionary public policies but it also served to shape notions of belonging for the excluded other.

This well-written and nuanced analysis of Tay-Sachs as a Jewish disease contains many additional insights relevant to current debates over racialisation projects that have intensified in medicine since the first draft of the human genome was announced in 2000. Attentive to the changing meanings of Tay-Sachs over time, Reuter demonstrates that racialisation operates on multiple terrains; it is about silences as much as what is visible. Enacted in a variety of ways, attaching racial meaning to Tay-Sachs also required ignoring or actively dismissing Tay-Sachs in non-Jews. Yet, for all the historical shifts 'what has remained constant throughout the history of this disease category is its deployment as a way to delineate, exclude, and regulate the other' (p. 118).

While some scholars have argued that scientific racism was rejected after the Second World War, Reuter's analysis of Tay-Sachs argues that there was no such retreat from scientific racism in the medical sphere. Testing Fate thus adds crucial insights to recent scholarly inquiries into how stigmatising narratives about race and racial difference persist in the ever-expanding era of genetic testing. This well-written and fascinating account of the history of a racialised disease should be read by both health care providers and scholars in a wide range of fields interested in the history of race and medicine.

\section{Lundy Braun}

Brown University, USA

doi: $10.1017 / \mathrm{mdh} .2017 .16$

Michael R. Trimble, The Intentional Brain (Baltimore, MD: John Hopkins University Press, 2016), pp. x, 308, \$29.95, hardback, ISBN: 978-1-4214-1949-7.

Michael Trimble is the doyen of British neuropsychiatrists. After a sparkling undergraduate career in Birmingham, he ascended rapidly to a consultant appointment at the heart of British neurology, the National Hospital for Neurology and Neurosurgery in Queen Square in London. He remained there for almost thirty years before partial retirement, spending the last ten of these as Professor in Behavioural Neurology. It is revealing that while his primary affiliation was with psychiatry, his appointments at Queen Square were as 'physician' and 'neurologist', in admirable defiance of the frequently rigid separation between neurology and psychiatry. Who better, therefore, to reflect on the history of the relationship between these two disciplines in a book devoted to the 'development of modern neuropsychiatry'?

The importance of history is one of his two leading themes, and this book is primarily an historical survey of the evidence and attitudes that have gradually shaped our understanding of the relationship between disorders of mind and brain. Indeed, born of a lifetime's reading on the subject, The Intentional Brain is a treasure trove of fascinating data from the past. Almost all, it seems, of our current controversies were anticipated by our intellectual ancestors. One of the book's great strengths is to reveal the subtleties of their thinking, refuting the easily made, but often false, assumption that contemporary science is dispelling the errors of history when in fact it may be reinstating the wisdom of the past.

Thus of the much vilified Franz Gall's (1758-1828) five principles - '(1) the brain is the organ of the mind, (2) the mind can be analysed into independent faculties, (3) these 